\title{
Assessment of Undiscovered Oil and Gas Resources of the North Sakhalin Basin Province, Russia, 2011
}

Using a geology-based assessment methodology, the U.S. Geological Survey estimated volumes of undiscovered, technically recoverable, conventional petroleum resources for the North Sakhalin Basin Province of Russia. The mean volumes were estimated at 5.3 billion barrels of crude oil, 43.8 trillion cubic feet of natural gas, and 0.8 billion barrels of natural gas liquids.

\section{Introduction}

The U.S. Geological Survey (USGS) estimated volumes of undiscovered, technically recoverable, conventional oil and gas resources of the North Sakhalin Basin Province in Russia. The assessment is part of a program to estimate petroleum resources for priority basins around the world, specifically for total petroleum systems (TPS) and assessment units (AU) that are defined on the basis of their geologic attributes that are favorable for the generation and accumulation of petroleum. The western portion of the neighboring Deryugin Basin Province was assessed along with the North Sakhalin Basin Province (fig. 1) because the one defined TPS, the Cenozoic Composite TPS, spans both provinces. Hereafter, both areas are referred to only as the North Sakhalin Basin Province. The

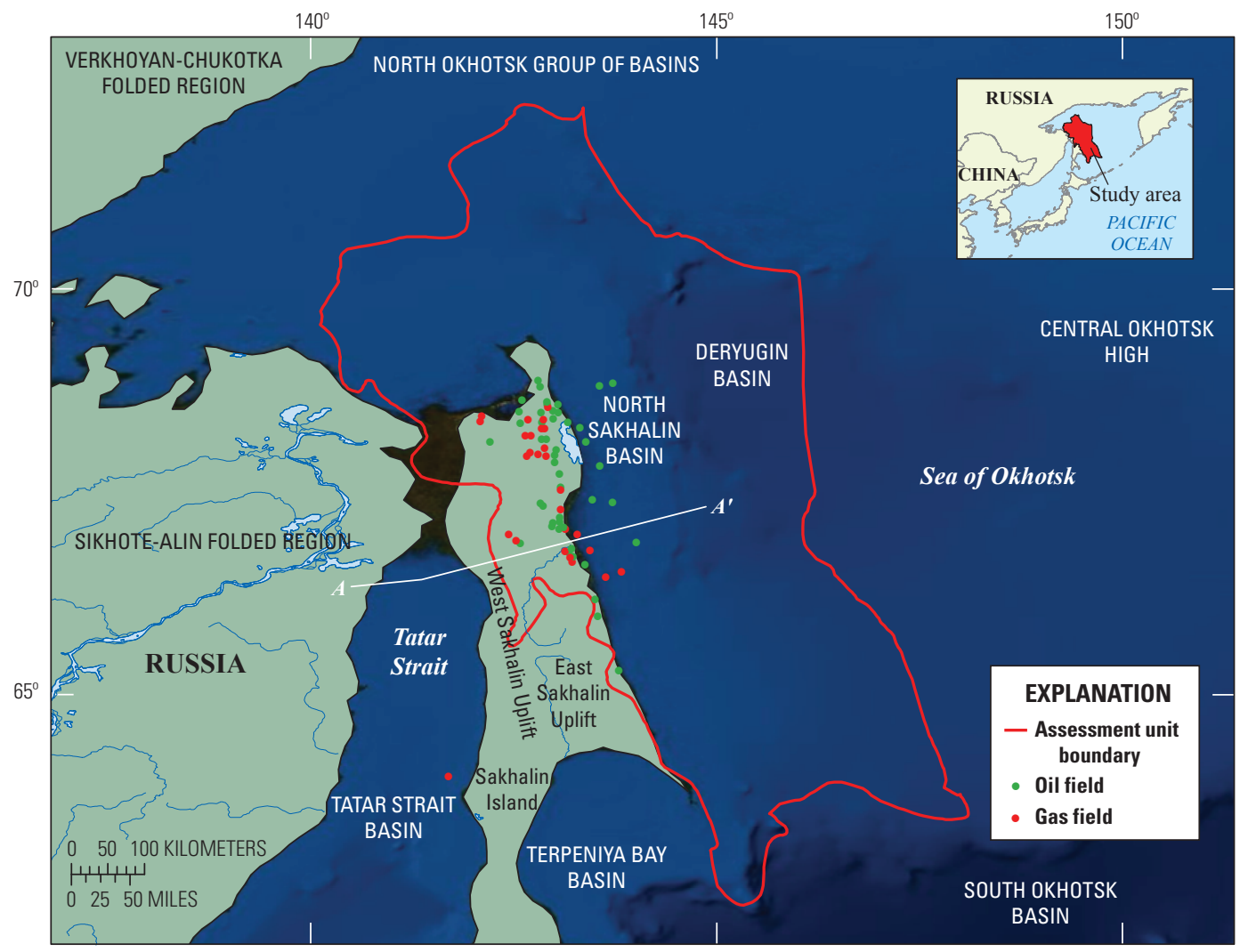

Figure 1. Generalized map showing the boundary of the North Sakhalin Basin Assessment Unit, centerpoints of oil and gas fields, and the location of geologic cross section $A-A$ 'shown in figure $2 A$. The Cenozoic Composite Total Petroleum System boundary coincides with the boundary of the North Sakhalin Basin Assessment Unit. Field data from IHS Energy (2009); assessment unit boundaries were drawn based on North Sakhalin Basin and Deryugin Basin Geologic Province boundaries from Persits and others (1998) and Lindquist (2000). 
area assessed encompasses about 254,950 square kilometers. This assessment was based on published geologic information, commercial data from oil and gas wells and fields, and field production records.

\section{Total Petroleum Systems and Assessment Units}

The North Sakhalin Basin Province has a complex tectonic history. The North Sakhalin Basin is interpreted to have originated as an Early Cretaceous passive continental margin that was deformed by Cretaceous to Paleogene continental collision that involved subduction of oceanic crust and accretion of a volcanic arc. Accreted sedimentary wedges form the core of Sakhalin Island, upon which a Paleogene to Neogene prograding delta system (paleo-Amur delta) developed. The delta system was modified by several tectonic events throughout the Cenozoic. Strike-slip movements occurred during the early Cenozoic, and late Neogene transpression and inversion followed by Pleistocene extension and transtension formed many of the present-day structures (Lindquist, 2000).

The Cenozoic Composite TPS was defined for the North Sakhalin Basin Province (table 1) to include petroleum source and reservoir rocks of Cenozoic age. The TPS boundary coincides with the boundary of the North Sakhalin Basin AU, which contains conventional undiscovered oil and gas resources and was the only AU defined geologically within the North Sakhalin Basin Province-North Sakhalin Basin AU (figs. 1, 2). A second
AU possibly containing continuous accumulations, in Oligocene to lower Miocene self-sourced siliceous rocks, was identified, but was not quantitatively assessed in this study.

Major source rocks in the North Sakhalin Basin Province primarily are upper Oligocene(?) to lower Miocene deep-marine diatomaceous mudstones. Lower to middle Miocene continental to pro-deltaic carbonaceous to coaly mudstones and marine mudstones are possible source rocks (Lindquist, 2000). The onshore and western offshore parts of the North Sakhalin Basin AU contain greater amounts of continental sediments and are mainly gas-prone, whereas the eastern part containing greater amounts of marine sediments is mainly oil-prone. Peak oil was generated during the Miocene and Pliocene (Lindquist, 2000). Most known recoverable crude oil and natural gas were discovered in Miocene to Pliocene clastic rocks of the delta system, although some reservoirs exist in Oligocene to lower Miocene fractured siliceous rocks and fractured pre-Cenozoic serpentinites. Seal rocks are primarily Miocene to Pliocene mudstones. Identified traps include anticlines, faulted anticlines, faults and fault blocks, various stratigraphic features (for example, depositional and unconformity pinchouts, facies changes) and hydrodynamic traps. High potential for discoveries exists in the offshore part of the North Sakhalin Basin Province in shelf-slope and basin-floor facies (for example, channels, fans, turbidites).

Table 1. North Sakhalin Basin Province assessment results (undiscovered, technically recoverable, conventional resources).

[MMB, million barrels; BCF, billion cubic feet. Results shown are fully risked estimates. For gas fields, all liquids are included under the natural gas liquids (NGL) category. F95 denotes a 95-percent chance of at least the amount tabulated. Other fractiles are defined similarly. Fractiles are additive under the assumption of perfect positive correlation. TPS, total petroleum system; AU, assessment unit. Gray shading indicates not applicable]

\begin{tabular}{|c|c|c|c|c|c|c|c|c|c|c|c|c|c|c|}
\hline \multirow{3}{*}{$\begin{array}{l}\text { Total petroleum systems (TPS) } \\
\text { and assessment units (AU) }\end{array}$} & \multirow{3}{*}{$\begin{array}{l}\text { Field } \\
\text { type }\end{array}$} & \multirow{3}{*}{$\begin{array}{c}\text { Mean (expected) } \\
\text { largest } \\
\text { field size } \\
\text { (MMB or BCF) }\end{array}$} & \multicolumn{12}{|c|}{ Total undiscovered resources } \\
\hline & & & \multicolumn{4}{|c|}{ Oil (MMB) } & \multicolumn{4}{|c|}{ Gas (BCF) } & \multicolumn{4}{|c|}{ NGL (MMB) } \\
\hline & & & F95 & $\mathrm{F} 50$ & F5 & Mean & F95 & F50 & F5 & Mean & F95 & F50 & F5 & Mean \\
\hline \multicolumn{15}{|c|}{ North Sakhalin Basin Province, Cenozoic Composite TPS } \\
\hline \multirow{2}{*}{ North Sakhalin Basin AU } & Oil & 1,000 & 1,791 & 4,776 & 10,850 & 5,345 & 5,989 & 16,592 & 39,520 & 18,874 & 63 & 177 & 427 & 202 \\
\hline & Gas & 5,350 & & & & & 8,001 & 22,091 & 51,784 & 24,933 & 178 & 490 & 1,151 & 555 \\
\hline $\begin{array}{l}\text { Total undiscovered petroleum } \\
\text { resources }\end{array}$ & & & & & & 5,345 & & & & 43,807 & & & & 757 \\
\hline
\end{tabular}


A

WEST

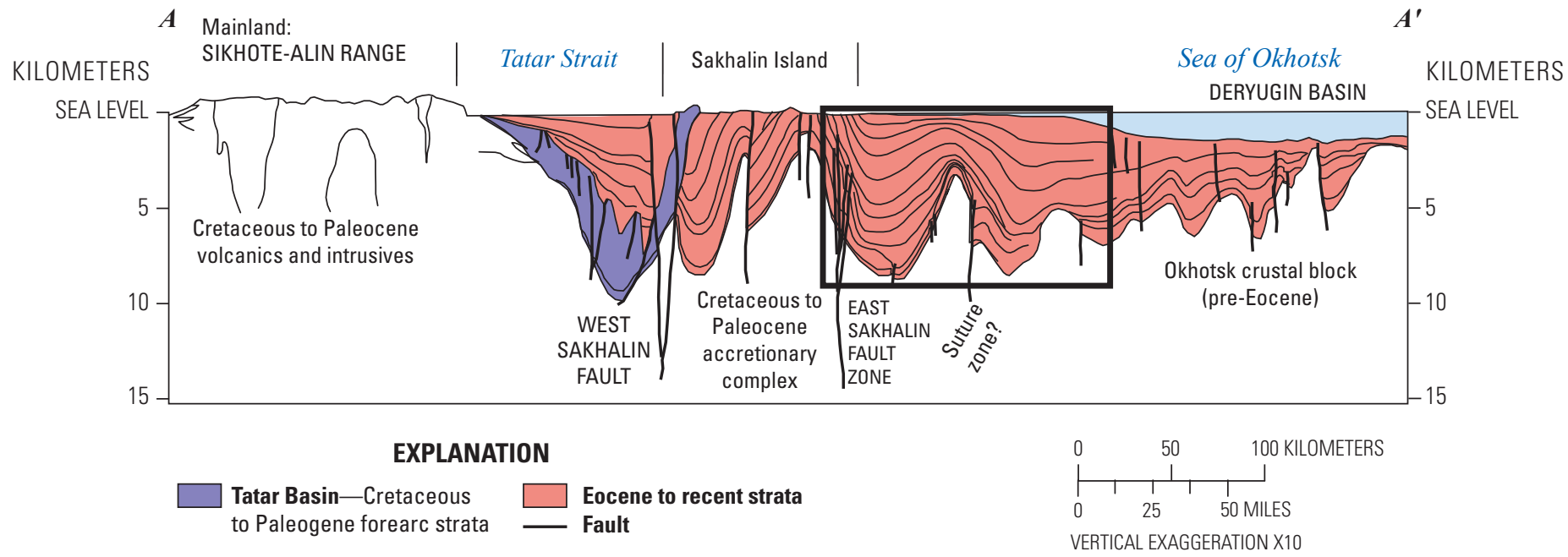

$\boldsymbol{B}$

WEST

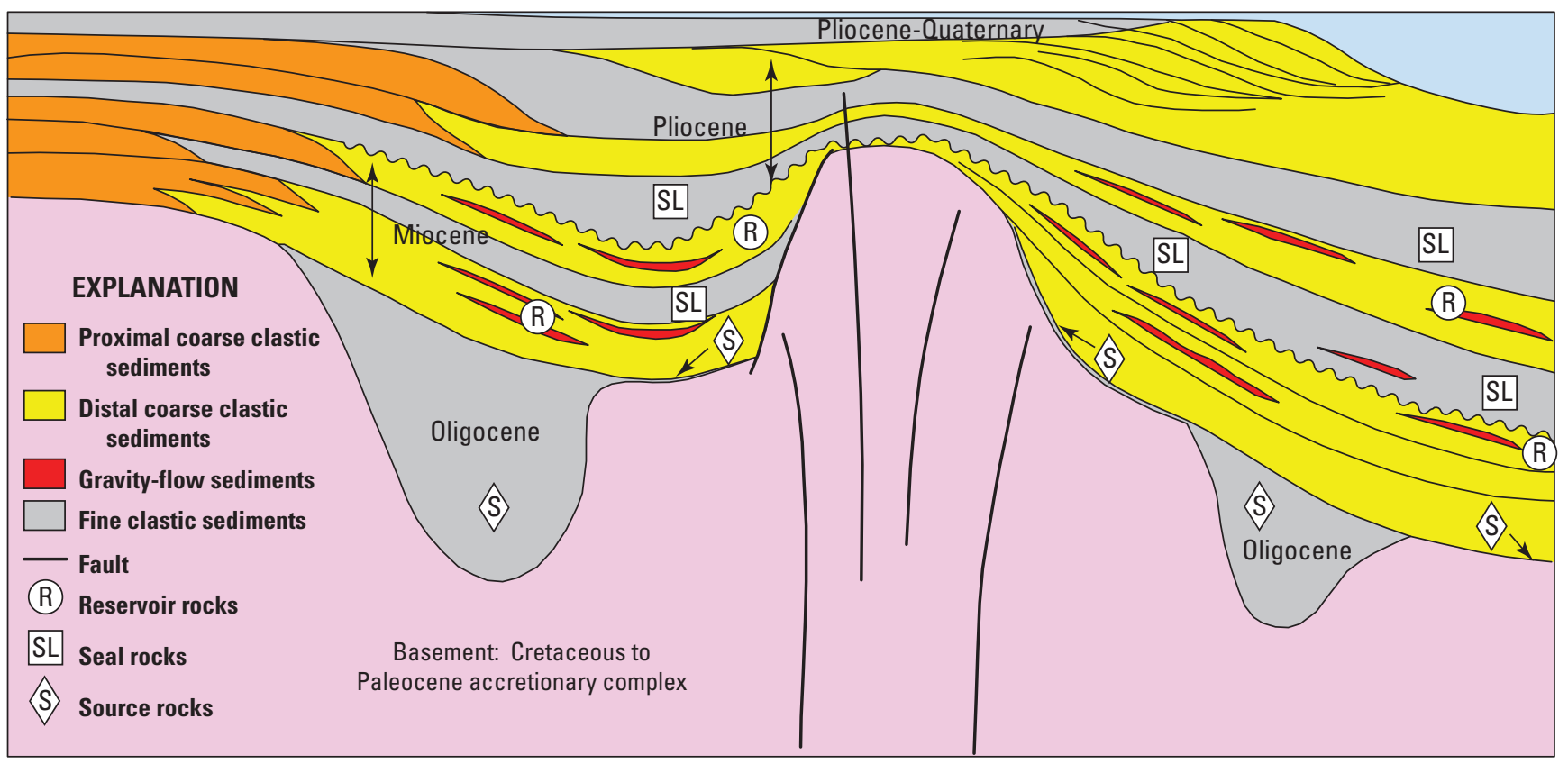

Figure 2. Geologic cross sections across the North Sakhalin Assessment Unit. A. West-to-east regional structural cross section of the Sakhalin area, North Sakhalin Basin Province, Russia (from Lindquist, 2000; after Worrel and others, 1996). Location shown in figure 1. Inset box represents the approximate location of a geologic model of petroleum occurrence shown in figure $2 B$. $B$. A geologic model of petroleum occurrence, North Sakhalin Basin Province, Russia (modified from Kharakhinov, 2010). 


\section{Assessment Results}

Estimates of volumes of undiscovered technically recoverable, conventional oil and gas resources are shown in table 1 . No attempt was made to estimate economically recoverable resources because it is beyond the scope of this study. In summary, the estimated mean volumes of undiscovered, technically recoverable, conventional oil and gas resources for the North Sakhalin Basin Province are about 5,345 million barrels (MMB) of crude oil, 43,807 billion cubic feet (BCF) of natural gas $(18,874$ $\mathrm{BCF}$ of associated and dissolved natural gas and 24,933 $\mathrm{BCF}$ of nonassociated natural gas), and $757 \mathrm{MMB}$ of natural gas liquids (202 MMB of natural gas liquids in oil accumulations and $555 \mathrm{MMB}$ of total liquids in nonassociated gas accumulations).

\section{For Further Information}

Supporting geologic studies of total petroleum systems and assessment units, and reports on the methodology used in the assessment of the North Sakhalin Basin Province, as well as the assessment results, are available at the USGS Central Energy Resources Science Center website: http://energy.usgs.gov.

\section{North Sakhalin Basin Province Assessment Team}

T.R. Klett (tklett@usgs.gov), Christopher J. Schenk, Craig J. Wandrey, Ronald R. Charpentier, Michael E. Brownfield, Janet K. Pitman, Richard M. Pollastro, Troy A. Cook, and Marilyn E. Tennyson.

\section{References Cited}

IHS Energy, 2009 [includes data current through October 2009], International exploration and production database: Englewood, Colo., IHS Energy.

Lindquist, S.J., 2000, The North Sakhalin Neogene Total Petroleum System of eastern Russia: U.S. Geological Survey Open-File Report 99-50-O, 18 p.

Kharakhinov, V.V., 2010, Oil-and-gas geology of the Sakhalin region: Moscow, Scientific World, 275 p. (in Russian).

Persits, F.M., Ulmishek, G.F., and Steinshouer, D.W., 1998, Map showing geology, oil and gas fields, and geologic provinces of the former Soviet Union: U.S. Geological Survey Open-File Report 97-470-E, CDROM.

Worrel, D.M., Kruglyak, V., Kunst, F., and Kuznetsov, V., 1996, Tertiary tectonics of the Sea of Okhotsk, Russia: Far-field effects of the India-Eurasian collision: Tectonics, v. 15 , no. 4, p. 813-826. 